\title{
Flow Curves of Mixtures of Acrylonitrile-Styrene Copolymers with Different Molecular Weights at Extremely High Shear Rates
}

\author{
Hideroh Takahashi, Yoshinori Inoue, Satoru Yamamoto, \\ and Osami Kamigaito \\ Toyota Central Research and Development Laboratories, Inc. \\ Nagakute-cho, Aichi-gun, Aichi-ken 480-11, Japan
}

\begin{abstract}
The flow curves of mixtures of acrylonitrile-styrene copolymers with the same S/AN ratio $(70 / 30)$ and different molecular weights $\left(\mathrm{SAN}-1 ; M_{\mathrm{w}}=1.88 \times 10^{5}, \mathrm{SAN}-2 ; M_{\mathrm{w}}=\right.$ $\left.6.5 \times 10^{4}\right)$ were measured up to the shear rate of $10^{7} \mathrm{~s}^{-1}$. The second Newtonian and the second non-Newtonian region were observed for SAN-1 ,SAN-2 and their mixtures $\left(<10^{6} \mathrm{~s}^{-1}\right)$ following the first non-Newtonian region. The viscosity decreased with decrease of molecular weight (increase of SAN-2 content) and the gradient of the flow curve (log viscosity vs. log shear rate) of the mixture became smaller with decrease of molecular weight in the first non-Newtonian region. Flow behavior of the mixture was quite different from that of the immiscible polymer blends. The flow curves of SAN with different molecular weights $\left(\geq 1.28 \times 10^{5}\right)$ united into one curve at the shear rates higher than $5 \times 10^{5} \mathrm{~s}^{-1}$.
\end{abstract}

Key words: High Shear Viscosity / Molecular Weight / Polymer Blend

\section{分子量の異なるアクリロニトリルスチレン共重合体混合物の 超高せん断速度下の溶融流動特性}

\author{
高橋 秀郎・井上 良德・山本智・上垣外修己*
}

（原稿受理：1990年 2 月13日）

\section{1. 緒言}

前報に扣いて, 非相容系高分子ブレンドの高せん断速度下の溶 融流動では, 低粘度成分の一部が系全体の見かけのせん断速度よ り高いせん断速度で流動するために, 系全体の粘度が低粘度成分 に支配されることを明らかにするととるに，流動特性計算モデル を構築した ${ }^{12,2)}$. 本報では, 相容系高分子ブレンドの高せん断速 度下の溶融流動特性の特徵を検討する. 相容系高分子対としては, (1)分子構造は同じで，両成分の主たる違いが分子量にある場合 （ガラス転移温度 $T_{\mathrm{g}}$ の差が小さい）と，(2)分子構造が異なり， 両成分の $T_{\mathrm{g}}$ が大きく相違する場合が考光られるが，ここでは(1) の場合を取り上げる。

高分子液体のレオロジー的研究の立場からは, 分子量, 分子量 分布，枝分れあるいは高分子鎖の化学構造などの点で，よく特性

* (株)豊田中央研究所 $\mathbf{T} 480-11$ 愛知県愛知郡長久手町
解析された試料を用いることが必須の条件である。その結果，分 子量分布が非常に狭い単分散高分子とそれらの混合物を用いるこ とにより, 多くの基礎的な研究が行われてきた。 これらの基礎的 な研究を通して, 高分子液体のレオロジー的性質に及ぼす分子量, 濃度, 分子量分布, 枝分れの影響などの学問的にも工業的にも重 要な多くの知見が得られている

本報では, 分子量の異なる二つのアクリロニトリルスチレン共 重合体 (SAN) 試料混合系を用い，107 $\mathrm{s}^{-1}$ に至る高せ几断速度領 域に打ける溶融流動特性を明らかにするとともに, 従来の理論に よる考察を試みる.さらに, 非相容系高分子ブレンドの溶融流動 特性との違いについて検討する。

\section{2. 実 験}

$2 \cdot 1$ 測 定

超高速射出装置 ${ }^{2}$ を使用して, 分子量の異なる 2 種類の SAN 及びそれらの混合物を射出した，キャピラリーからの射出時の流 
量と圧力を計測し，見かけの粘度 $\eta_{\mathrm{a}}$ と見かけのせん断速度 $\dot{\gamma}_{\mathrm{a}}$ を 求めた. この測定に用いたキャピラリーは, 長さ $10 \mathrm{~mm}$, 直径 $0.5 \mathrm{~mm}$ のものである. $10^{4} \mathrm{~s}^{-1}$ 以下の低せん断速度領域の溶融流 動特性を, 市販のキャピラリーレオメータ（キャピログラフ，東

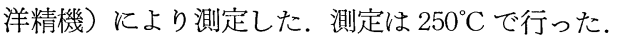

2 種類の SAN 及びそれらの混合物の分子量分布を, 高速液体 クロマトグラフ (日本分光, TRI ROTAR 型) を用いて, ゲル 透過クロマトグラフィー (GPC) により測定した。溶媒にはテト ラヒドロフラン (THF) を用いた。陚料は共重合体であるため, スチレンニニットとアクリロニトリルニニットの分布が重合度に よって異なる可能性があり，それらが異なれば GPC で求めた平 均分子量の信頼性に問題が生じる，そこで両ニニットの分子量に 対する分布を, 液体クロマトグラフィー/フーリエ変換赤外分光 (LC/FTIR) 法を用いて，あらかじめ測定した。 まず，試料を GPC 型の液体クロマトグラフで分別した．各分別物についてフ ーリエ変換赤外分光計で，アクリロニトリルニニットのニトリル 基の逆対称伸縮振動 $(-C \equiv N)$ と, スチレンニニットのベンゼ ン環の面外変角振動の吸収量を測定した.

2 種類の SAN 及びその混合物のペレットを, 通常の射出成形 機により, 樹脂温度 $250^{\circ} \mathrm{C}$, 金型温度 $60^{\circ} \mathrm{C}$ で矩形試験片に成形し た. 矩形試験片より幅 $4.5 \mathrm{~mm}$, 厚さ $2.0 \mathrm{~mm}$, 長さ $35 \mathrm{~mm}$ の試料 を機械加工により作製し，粘弾性スペクトルを測定した．粘弾性 スペクトルは, 粘弾性スペクトロメータ（安本製作所）を用い, 周波数 $10 \mathrm{~Hz}$, 歪み $0.01 \mathrm{~mm}$ の条件下で測定した.

\section{$2 \cdot 2$ 試 料}

分子量の異なる 2 種類のアクリロニトリルスチレン共重合体 (SAN-1, SAN-2：三菱モンサント化成）とそれらの混合物を試 料として用いた。 混合比は SAN-1/SAN-2 $=70 / 30,50 / 50,30 / 70$ とした. SAN-1, SAN-2 ともにアクリロニトリルの分率は約 30 \%である。

混合物は 2 種類の SAN をあらかじめ良く混合しておき， 2 軸 押出機（ナカタ二）を用いて樹脂温度 $240^{\circ} \mathrm{C}$ で溶融混合の後, 直 径約 $3 \mathrm{~mm}$ の押出物を水冷の後, ペレタイザーで切断し, 長さ 3 〜 4mm のペレットにした.

\section{3. 結果及び考察}

Fig. 1 飞 SAN-1, SAN-2 及び混合物の分子量分布を，Table I に重量平均分子量 $M_{\mathrm{w}}$, 数平均分子量 $M_{\mathrm{n}}$ と $M_{\mathrm{w}} / M_{\mathrm{n}}$ を示す. SAN-1, SAN-2 に比して, 混合物は広い分子量分布をしている

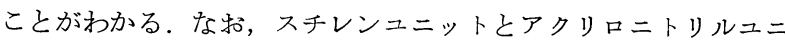
ット分子の量に対する分布を前述の LC/FTIR 法で測定したとこ ろ, SAN-1, SAN-2 及び各々の分別物で，スチレン/アクリロ ニトリル (S/AN) がほとんど同じであった (SAN-1 : S/AN= $71 / 29, \mathrm{SAN}-2: \mathrm{S} / \mathrm{AN}=70 / 30)$. この結果，分子量は GPC そよ る測定で問題ないことがわかった.

Fig. 2 亿 SAN-1, SAN-2 及び混合物の損失正接の温度依存 性を示す．両成分のガラス転移温度の中間で，損失正接-温度曲 線に，いずれも唯一つのピークが観測された．これは相容系高分 子混合物（ブレンド）の一般的特徴を反映しているものと考觉ら れる ${ }^{9)}$. このピーク温度は混合物のガラス転移温度 $T_{\mathrm{g}}$ に対応す る. $T_{\mathrm{g}}$ は低分子量成分である $\mathrm{SAN}-2$ の分率が増加するに従い 低温側に移動した. Fig. 3 に SAN-1-SAN-2 混合物の $T_{\mathrm{g}}$ の

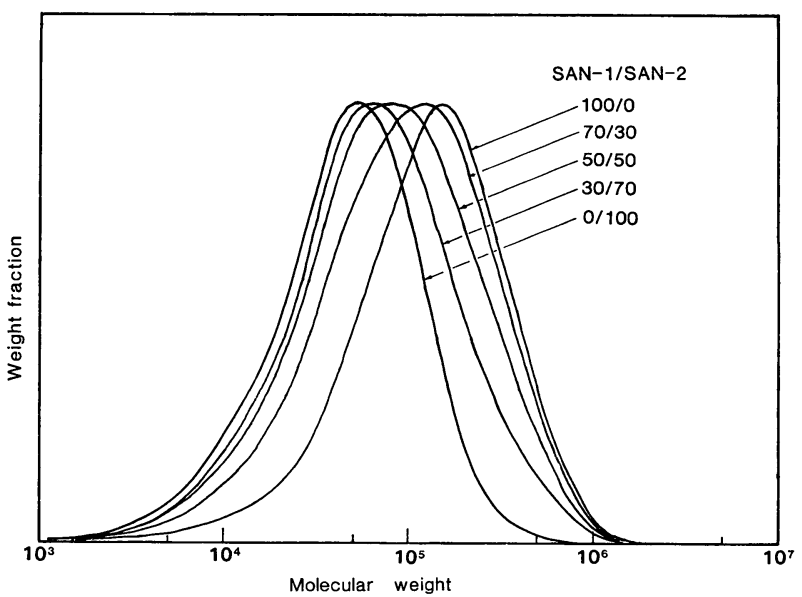

Fig. 1 Molecular weight distribution of SAN-1, SAN-2 and their mixtures.

Table I. Molecular weight of SAN-1, SAN-2 and their mixtures.

\begin{tabular}{c|c|c|c}
\hline \multirow{2}{*}{ Polymer } & \multicolumn{3}{|c}{ Molecular weight } \\
\cline { 2 - 4 } & $M_{\mathrm{w}}$ & $M_{\mathrm{n}}$ & $M_{\mathrm{w}} / M_{\mathrm{n}}$ \\
\hline SAN-1 & $1.88 \times 10^{5}$ & $6.38 \times 10^{4}$ & 2.95 \\
SAN-1(70\%)-SAN-2(30\%) & $1.52 \times 10^{5}$ & $4.46 \times 10^{4}$ & 3.41 \\
SAN-1(50\%)-SAN-2(50\%) & $1.28 \times 10^{5}$ & $3.57 \times 10^{4}$ & 3.59 \\
SAN-1(30\%)-SAN-2(70\%) & $1.06 \times 10^{5}$ & $3.15 \times 10^{4}$ & 3.37 \\
SAN-2 & $6.50 \times 10^{4}$ & $2.51 \times 10^{4}$ & 2.59 \\
\hline
\end{tabular}

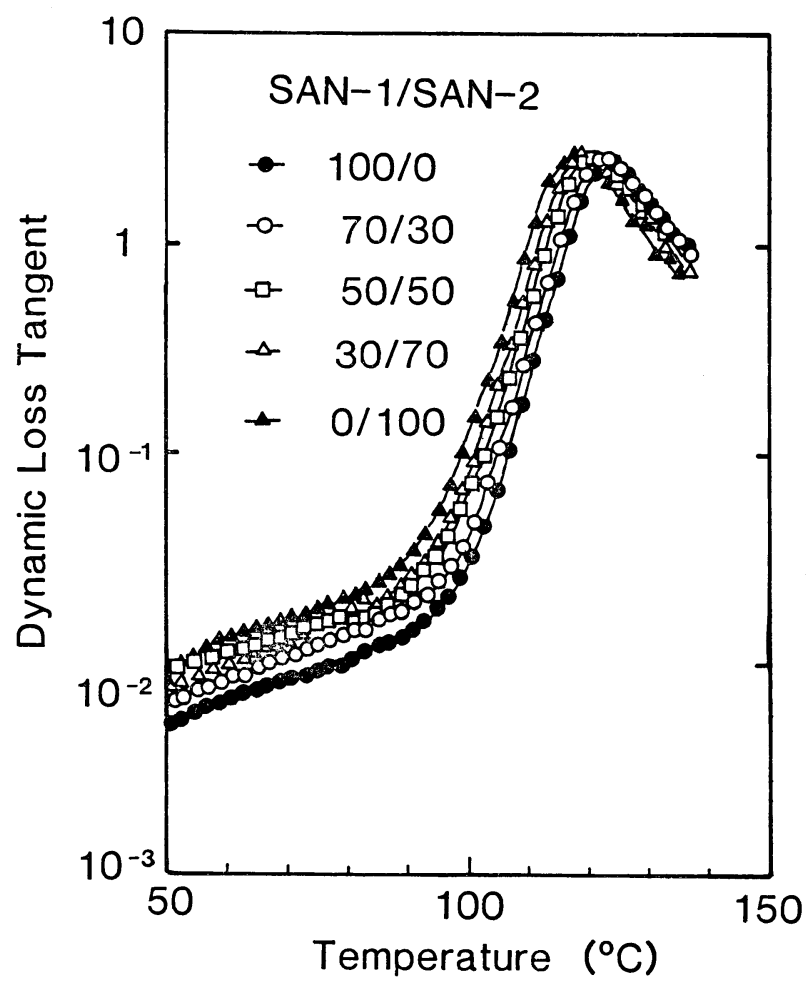

Fig. 2 Dynamic loss tangent of SAN-1, SAN-2 and their mixtures. 


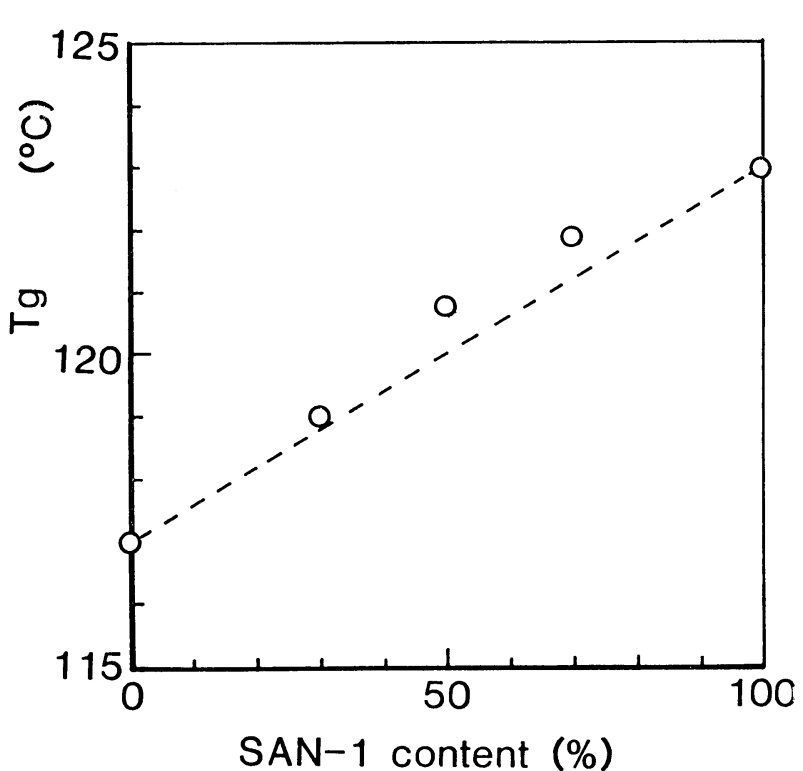

Fig. 3 Plot of glass transition temperature against SAN-1 content.

SAN-1 分率に対する依存性を示す。破線は, 二つの相容性高分 子の混合物のガラス転移温度 $T_{\mathrm{g}}$ と混合比との関係に関する Fox の式 ${ }^{10)}(1)$ にる計算值である。実測值と計算值はほ涪一致し，

SAN-1 と SAN-2 が相容した形態で混合していることがわかる.

$$
\frac{1}{T_{\mathrm{g}}}=\frac{W_{1}}{T_{\mathrm{g} 1}}+\frac{W_{2}}{T_{\mathrm{g} 2}}
$$

ここで， $T_{\mathrm{g} 1}, \mathrm{~T}_{\mathrm{g} 2}$ はそれぞれ高分子 1,2 の $T_{\mathrm{g}}$ であり, $W_{1}, W_{2}$ はそれぞれ高分子 1,2 の重量分率である。

SAN-1-SAN-2 混合物の流動曲線を Fig. 4 亿示す. SAN-1, SAN-2 いずれの流動曲線も第 1 次非ニュートン流動域, 第 2 次 ニュートン流動域, 及び第 2 次非ニュートン流動域を示した. 分 子量の高い SAN-1 の粘度が分子量の低い SAN-2 の粘度より高 く, 同一温度での流動曲線は SAN-1 のものが SAN-2 のものの 上方飞位置した。第 1 次非ニュートン流動域に括いて, SAN-1 の勾配よりも SAN-2 の勾配が緩やかであった。混合物の流動曲 線は SAN-1, SAN-2 の流動曲線の間に混合比の順に配列した.

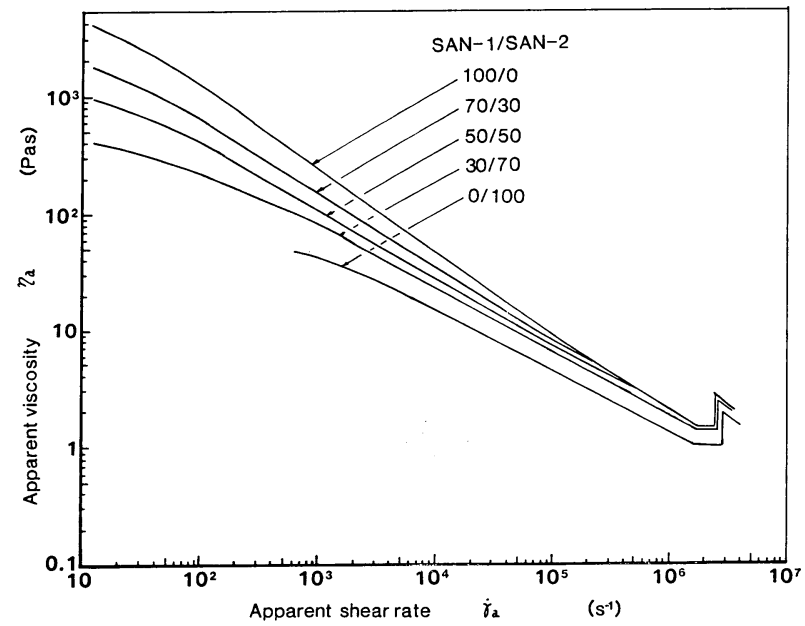

Fig. 4 Flow curves for SAN-1, SAN-2 and their mixtures in high-shear-rate region.
また, 混合物の流動曲線は SAN-1 に比較して変化が緩やかであ り, SAN-1 70\%-SAN-2 30\%, SAN-1 50\%-SAN-2 50\% 混 合物の流動曲線は，せ九断速度 $5 \times 10^{5} \sim 10^{6} \mathrm{~s}^{-1}$ 以上の領域に扣い て, SAN-1 の流動曲線に重なった. SAN-1 30\%一SAN-2 70\% 混合物と SAN-2 の流動曲線は，他の流動曲線と重ならなかった。 この実験結果は，単分散ポリスチレン同志の混合物を用いて， $10^{4} \mathrm{~s}^{-1}$ 以下の領域で得られている研究結果をもとに, 次の上うに 考察される.すなわち， 2 種類の単分散高分子混合物の定常流粘 度のせん断速度依存性（流動曲線）は, 親成分の流動曲線の間に 配列し，からみ合いの緩和に関する緩和時間の分布が二つ存在 するために 2 段飞変化する ${ }^{3), 7), 8,11)}$. 本実験で用いた SAN-1, SAN-2 の上5に互に広い分子量分布をるつ高分子同志の混合物 では，この 2 段の変化が連続的に生じるため勾配が緩かとなる. また, 分子量の異なるポリスチレンの流動曲線はせん断速度の高 いところで 1 本の曲線に合一する3),77,8),11),12) ことが明らかにさ れているが, SAN-1 と SAN-2 の混合物は, 互に広い分子量分 报をるち，その上平均分子量が一桁近く異なる高分子同志の混合 物のため, $10^{6} \mathrm{~s}^{-1}$ に近い超高せ九断速度領域で, はじめて SAN1 と SAN-1 70\%-SAN-2 30\%, SAN-1 50\%-SAN-2 50\%混 合物の流動曲線の合一が観測されたものと考えられる. SAN-1 30\%-SAN-2 70\% 混合物と SAN-2 の流動曲線は，合一する前 飞第 2 次ニュートン流動が生じるため，結局合一に至らなかった ものと考えられる．Fig. 5 にせん断速度を一定にとったとさの

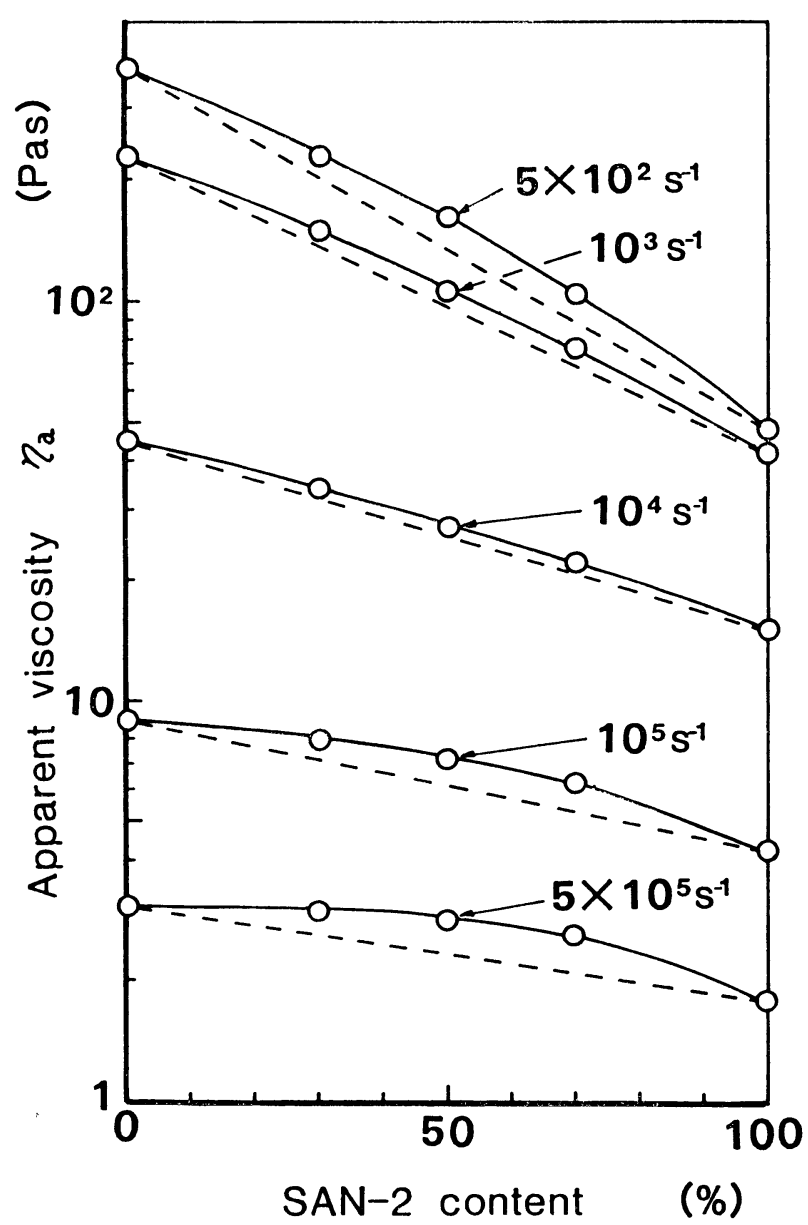

Fig. 5 Apparent viscosity $\eta_{\mathrm{a}}$ vs. SAN-2 content. 
粘度 $\eta_{\mathrm{a}}$ と，SAN-2 の重量分率の関係を示す．図中の破線は，対 数型の 加成則式 $\left.(2)^{13)},{ }^{14}\right)$ に基づく計算值である．対数型の加成則 は，相容系混合物の粘度の記述に適用されている ${ }^{15), 16)}$

$\log \eta=\phi_{\mathrm{A}} \log \eta_{\mathrm{A}}+\phi_{\mathrm{B}} \log \eta_{\mathrm{B}}$

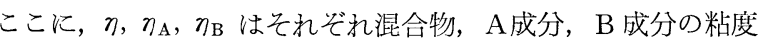
であり， $\phi_{\mathrm{A}}, \phi_{\mathrm{B}}$ はそれでれ $\mathrm{A}$ 成分, $\mathrm{B}$ 成分の体積分率で， $\phi_{\Lambda}+\phi_{\mathrm{B}}$ $=1$ となる.

この結果より, SAN-1－SAN-2 混合物については, $10^{3} 〜$ $10^{4} \mathrm{~s}^{-1}$ のせん断速度範囲で対数型の加成則が注涪成り立つことが わかる。せん断速度の高い領域では，一部の混合物の流動曲線は 高粘度の SAN-1 の流動曲線に合一した。 また，せん断速度の低 い領域に招いても，混合物の粘度は高粘度成分の寄与が大きな側 に偏った值となった。

一方， 非相容系高分子ブレンドでは， 既報1),2)で述べたように 流動曲線は，低粘度成分の影響を強く受けて低粘度側に極めて似 た挙動をするという特徴があった。

以上の結果, 分子構造は同じで, 分子量の異なる（ガラス転移 温度 $T_{\mathrm{g}}$ の差が小さい)相容系高分子混合物の流動曲線の特徴は, せん断速度の増加に伴い，低分子量のものの流動曲線の勾配が緩か となり，その流動曲線が高分子量のものの流動曲線に漸近し，見 かけ上は高粘度成分の影響を強く受けるように振舞う点にあると 結論することができる。

\section{4. 結 論}

相容系高分子対の典型的な例として，分子構造は同じで，両成 分の主たる違いが分子量にある場合（ガラス転移温度 $T_{\mathrm{g}}$ の差が 小さい）を取り上げ，それらの混合物の高せん断速度下の溶融流 動特性を測定した。試料はアクリロニトリルスチレン共重合体と した．その結果，互いに分子量の異なる同種の高分子の混合物の 流動曲線の特徴は，せん断速度の増加にともない低分子量のもの の流動曲線の公配が緩かになり，その流動曲線が高分子量のもの の流動曲線に漸近し，見かけ上は高粘度成分の影響を強く受ける ように振舞う点にあることがわかった。この举動は，非相容系高 分子ブレンドの流動曲線とまったく異なるものであり，分子鎖同
志が互いに混合しているレベルの高分子混合物の特徴と考えられ る。

謝辞 本研究の遂行にあたり，終始ご指導いただいた京都大学化

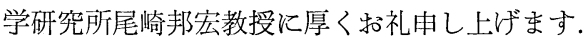

\section{文献}

1) Takahashi, H., T. Matsuoka, T. Ohta, K. Fukumori, T. Kurauchi, and O. Kamigaito, J. Appl. Polym. Sci., 37, 1837 (1989).

2）高橋秀郎, 小岩井明彦, 上垣外修已, 日本レオロジー学会 誌, 17, 150 (1989).

3）升田利实郎，日本レオロジー学会誌，12，7 (1984).

4) Onogi, S., T. Masuda, and K. Kitagawa, Macromolecules, 3, 109 (1970).

5) Masuda, T., K. Kitagawa, T. Inoue, and S. Onogi, Macromolecules, 3, 116 (1970).

6) Onogi, S., T. Masuda, I. Shiga, and F.M. Costaschuk, Appl. Polym. Symp., 20, 37 (1973).

7）升田利史郎，博士論文，京都大学 (1973).

8）木内政行, 高橋雅與, 升田利史郎, 小野木重治, 日本レオ ロジー学会誌，4，25（1976）

9）秋山三郎，“ポリマーブレンド”，シーエムシー，第 2 章 (1981).

10) Fox, T.G., Bull. Am. Phys. Soc., 1, 123 (1956).

11）小野木重治, 升田利史郎，高分子， 17，640（1968）.

12) Stratton, R.A., J. Colloid and Interface Sci., 22, 517 (1966).

13）野原繁三，高分子化学，12，527（1955).

14) Plochocki, A., "Polymer Blends", Vol. 2, Academic Press (1978), Chap. 21.

15）泉善三，“ポリマーアロイ”，高分子学会編，東京化学同人， 第5.10節 (1981).

16）藤井栄磨，愛知県工業指導所報告，3，30（1967）. 